\title{
OBSERVATIONAL AND EXPERIMENTAL EVI- DENCES RELATING TO THE ORIGIN AND DIFFERENTIATION OF THE DEFINITIVE GERM CELLS IN MICE ${ }^{1}$
}

\author{
N. B. EVERETT \\ Department of Anatomy, University of Michigan, Ann Arbor \\ SIX PLATES (THIRTY-THREE FIGURES)
}

This study is an outgrowth of an earlier one on the origin of ova in the adult opossum (Everett, '42), in which the conclusion was reached that new ova are derived from the epithelium of the ovary. This conclusion is out of line with the view, held by many, that there is an early segregation of germ cells from which the definitive sex cells are derived. Although the germ cell question in vertebrates has received considerable attention since the initial work of Waldeyer (1870), it is still an unanswered one. Numerous investigators have attacked the problem in all of the major vertebrate groups, but the conclusions reached have been at variance. The fundamental question to be answered, and one which has been responsible for these differences in opinion, is whether the definitive germ cells are derived from undifferentiated cells which are set aside early in development and which later migrate to the gonad, or whether they are merely transformed soma cells which originate in the gonad from time to time even in the adult.

It was hoped that a detailed study of the germ cell history in some mammal, beginning with the early embryonic stages through to sexual maturity, would be of considerable value in solving the germ cell question in this group. For this reason a careful study of Peromyscus maniculatus, and Mus musculus albinus was undertaken.

${ }^{1}$ Contribution from the Department of Zoology, University of Michigan. 
Excellent reviews of the literature relating to the germ cell problem in vertebrates have appeared recently, so only brief reference to the most pertinent material seems necessary in this paper.

Investigators who have studied germ cells of different species of vertebrates have used various criteria for distinguishing them, such as their large size, large clear nuclei, distinct cell and nuclear membranes and presence of yolk granules. In addition, the Golgi apparatus, the nature of the mitochondria, specific staining reactions, notched nuclei, attraction spheres, characteristics of plasmosomes, etc. have been used as diagnostic characters of germ cells. The characters found useful in identifying germ cells in mice through the course of this investigation are their large size with distinct cell outline, faintly staining cytoplasm, and large, clear nuclei with one or two distinct plasmosomes from which radiate diffuse strands of chromatin. These diagnostic characters apply equally as well to the earliest recognizable germ cells in the embryo as to the germ cells in the differentiated sex gland.

I wish to express my gratitude and appreciation to Dr. Peter Okkelberg of the Zoology Department of the University of Michigan for his suggestions and criticisms through the course of the work; to Dr. L. R. Dice of the University of Michigan Laboratory of Vertebrate Biology for supplying the Peromyscus material; to Dr. Bradley M. Patten of the Anatomy Department of the University of Michigan Medical School for use of the $\mathrm{x}$-ray equipment; and to Dr. Wayne Whitaker of the Anatomy Department for his assistance with the $\mathrm{x}$-ray work.

MATERIALS AND METHODS

Peromyscus maniculatus was chosen for this study because it is used quite extensively in genetic research at the University of Michigan Laboratory of Vertebrate Biology where 
an abundance of material was available. The mice used were not of a pure strain, but a mixture of subspecies. In the course of the investigation difficulties were encountered with this mixed strain in the experimental work, and the original material was, therefore, supplemented by two strains of albino mice. One strain was from the Zoological Laboratory of the University of Michigan and the other was an inbred strain from Dr. C. C. Little's laboratory at Bar Harbor, Maine.

Attempts were made to obtain timed embryos by using the vaginal smear technique as a basis for mating the animals and making daily checks following mating for the presence of vaginal plugs. However, it was found that embryos of different litters which were of the same age varied considerably in size; thus, it was deemed more reliable to use crown rump measurements as a criterion for comparison. The embryos were fixed for 24 hours in Bouin's solution and then measured with vernier calipers to the nearest tenth of a millimeter. Since this study, subsequent to sex differentiation, is confined to the ovary only the female sex glands were collected after birth. The ovaries were removed and similarly fixed in Bouin's solution. Dioxane was used for dehydration and clearing, and paraffin for imbedding. All of the material was sectioned serially from 5 to $8 \mu$ in thickness, and stained in Heidenhain's iron hematoxylin. Most of the sections were counterstained with triosin.

Supplementary methods will be described in the experimental sections.

\section{MORPHOLOGICAL OBSERVATIONS ON PEROMYSCUS}

The first cells recognizable as germ cells appear in the wall of the hind gut of a $2.6-\mathrm{mm}$. embryo. In the earliest stages these are definitely among the entodermal cells and not in the splanchnic mesoderm of the gut as has been asserted in some cases (figs. 1, 2). As shown in figure 2, the germ cells are mesial to the basement membrane of the gut entoderm. The gut is the only site of germ cells in embryos of this size and in other stages up to $3 \mathrm{~mm}$. Discernible germ cells are not 
very numerous, but they are found scattered throughout the gut in the region which overlies the yolk sac. In 4-mm. embryos germ cells are still found in the gut entoderm, some in the splanchnic mesoderm, and some have made their way into the dorsal mesentery. By this time the urogenital ridge is distinguishable and the pro-mesonephric duct has differentiated. A slightly older embryo $(4.3 \mathrm{~mm}$.) reveals numerous germ cells within the dorsal mesentery and a few near the mesial portion of the urogenital ridge (figs. 4, 5). All of the germ cells have left the gut by this stage. It appear's that the germ cells make their way from the gut entoderm into the surrounding mesenchyme and through the dorsal mesentery to the genital portion of the urogenital ridge by amoeboid movements. The fact that the cells are among the mesenchyme cells of the mesentery and not within the surrounding mesothelium excludes the possibility of them being carried by the dorsal shifting of the mesothelium as has been suggested.

In 5-mm. embryos the germinal epithelium has begun to proliferate and is two cell layers in thickness along the ventral border. Several germ cells are among the epithelial cells and within the ventral mass are numerous cells exhibiting mitosis. It is practically impossible to determine whether the germ cells are dividing because a cell in division reveals no characteristies which are useful in its identification.

Between the 6 - and $10-\mathrm{mm}$. stages the following changes occur: the urogenital ridge enlarges and the genital part becomes separated by a groove from the wolffian body; an epithelial core forms within the genital body as a result of the continuous proliferation of the germinal epithelium; the entire urogenital body constricts from the dorsal body wall and becomes suspended by a thin mesentery; the müllerian duct appears at the dorso-lateral edge of the mesonephros; and the epithelium of the gonad becomes distinct at the lateral surfaces.

Sex can easily be distinguished in 10-mm. embryos. In the male the epithelial core is almost completely separated from 
the germinal epithelium. This separation is brought about by mesenchymal cells which grow in from the hilar region and come to lie between the germinal mass and the epithelium. This mesenchymal sheet marks the beginning of the tunica albuginea. Simultaneously with the formation of the tunica the epithelial core begins to be divided into sex cords by an invasion of mesenchyme which grows into the solid core. These mesenchymal ingrowths become the septulae of the gland which are continuous with the tunica along the ventral border of the testis. The gonad of the female at this stage is still composed of an unorganized mass of germ cells, but its sex may be distinguished by its smaller size. Proliferation of cells from the germinal epithelium soon ceases in the male, but continues in the female along the entire ventral surface.

In 12-mm. embryos the unorganized tissue of the ovary is beginning to divide into partitions by the ingrowth of mesenchyme into the epithelial core. Proliferation from the germinal epithelium continues until some time after birth, but is less abundant in the latter part of the gestation period. The cells arising from the epithelium push through the thin tunica albuginea into the deeper parts of the gland. The ovary at this stage, being somewhat rounded and much more compact than the testis, may readily be identified by dissection. In embryos of $18 \mathrm{~mm}$. the numerous oöcytes exhibit synizesis, a condition that is observed until shortly after birth. It is perhaps worth comment that the activity of the ovarian epithelium has at this stage become somewhat reduced along the ventral region but has increased near the hilus.

Embryos at birth vary in length from $22-26 \mathrm{~mm}$. At this time the gland is filled with oöcytes, most of which are surrounded by a single layer of flattened epithelial cells. These young follicle cells apparently have developed from undifferentiated epithelial cells of the ovarian surface. A few enlarged cells are present within the germinal epithelium which exhibit synizesis and thus can be identified as germ cells. Some of the germ cells in the deeper part of the ovary degenerate and it appears that some of their follicular cells 
form a part of the ovarian medulla. In addition, an ingrowth of mesenchyme from the hilus contributes to the medullary formations.

During the first week, post partum, the ovary increases considerably in size, the tunica albuginea becomes distinct, young follicles appear in the various stages of development, and numerous mitoses appear in the germinal epithelial cells (figs. 8, 9). Some of the young follicles are now surrounded by theca cells. It is difficult to trace the origin of the theca cells, but from their general appearance and staining reactions it appears that they are derived from cells of the tunica and the septulae.

About the middle of the second week there is an apparent decrease in the number of larger follicles within the ovaries. In ovaries of.13- and 14-day mice there is a marked wave of ova and follicle formation (fig. 11). Beneath the epithelium, particularly near the hilus, are hundreds of young ova, and within the deeper parts are follicles in varying stages of development. Within the germinal epithelium there are enlarged cells which simulate germ cells, and beneath the epithelium in the region of the hilus there are continuous chains of ova projecting into the cortex and into the medulla. These chain-like ingrowths are believed to be the so-called "Pflüger's tubes" which have been described by others.

In the third week there is a progressive increase in the size of the ovary until it approaches the condition of the adult gland by the twenty-second or twenty-third day (figs. 12,13). This increase in size results from a growth of the follicles, but there is a concomitant decrease in the number of young stages within the cortex. Some of the older follicles possess an antrum at this time, but none are ready to rupture. The majority of these older follicles show obvious signs of degeneration, since the oöcytes are vacuolated and shrunken and often exhibit maturation spindles. Also, many of the follicular cells have pycnotic nuclei, and leucocytes have invaded the follicles. The epithelium is stretched considerably and most of the cells are 
quite elongated. There are, however, still a few enlarged cells within the epithelium, especially at the hilar region.

No material changes occur within the ovary after the twentysecond and twenty-third day, until about 33 days post-partum. At this time there is apparently another peak of follicle formation since numerous oöcytes appear beneath the epithelium, and within the epithelium are a number of mitotic figures and enlarged cells. It is believed that this increase in ovarian activity is correlated with the oestrous cycle since this type of activity was found to be periodic in the older mice which ordinarily begin to breed at about 50 days post-partum.

A morphological study of a series of albino mice revealed that the development described above applies to these as well as to Peromyscus. A study of ovaries from pregnant animals showed that the formation of oöcytes and follicles did not cease altogether during pregnancy, but was greatly inhibited.

\section{DISCUSSION}

Observations on the early mouse embryos reveal cells within the gut entoderm that are unquestionably similar in appearance to the oogonia and spermatogonia which are found later in the gonads of the respective male and female individuals. Hargitt ('25) observed these cells in the rat and Simpkins ('23) observed them in the mouse and rat. Both Hargitt and Simpkins interpret them as enlarged cells which are in preparation for division and contend that such cells may be found scattered throughout the younger embryos, hence they are nothing but ordinary somatic cells and are in no sense the forerunners of the definitive sex cells. I have examined carefully every section of many mouse embryos with high magnification and $I$ have as yet to see any cells in the blood stream, neural tube, or in any part of the embryo that are identical with the germinal cells described above. It is true that there are enlarged cells in almost every organ of a young embryo, but these upon close examination can be distinguished from the so-called primordial germ cells found 
in the gut, and later in the dorsal mesentery and genital ridge. I feel that Hargitt is justified in calling many of the enlarged cells, shown in his figures, somatic cells because I, too, find such cells in the early mouse embryo, but in addition to these I find cells in the gut entoderm and later in the splanchnic mesoderm of the gut, and then in the dorsal mesentery which appear identical with those he figures in the genital ridge as germ cells.

Kingery ('17) and Brambell ('27), from their investigation of the germ cell problem in the mouse, concluded that the primordial germ cells develop from the germinal epithelium. Kingery found that there are two proliferations of cells from the germinal epithelium in the female, the first before birth giving rise to primordial germ cells, all of which degenerate, and the second after birth which result in the formation of the definitive ova.

Allen ('04) in his work on rabbit and pig embryos, Firket ('20) working with the chick and albino rat, and Bookhout ('37) with the guinea pig', have identified primordial germ cells in the early stages, but they are of the opinion that these all degenerate and play no part in the formation of the definitive germ cells. Thus, the primordial germ cells are believed to be only of historical significance, perhaps a cenogenetic character carried over from the lower forms.

In contrast to the findings of the above investigators, Rubaschkin ('08) working' with the guinea pig and rabbit, Fuss ('13) with human and other mammalian embryos, Vanneman ('17) with the armadillo, and Rauh ('26) with the rat, have traced the primordial germ cells from the gut entoderm to the genital ridge. They are convinced that these cells are the progenitors of the definitive sex cells. All of these workers contend that the germ cells migrate actively by amoeboid movements from the entoderm and through the dorsal mesentery to the genital ridge. Rubaschkin mentions a passive movement of the entire region above the gut by which the germ cells reach their definitive site. 
My findings are in close agreement with the last mentioned authors; however, I was not able to identify germ cells as early in development as Vanneman did. She first found them in the entoderm of the blastocyst stage, just as the entoderm was splitting from the ectoderm. It appears that this site of the germ cells is significant since the mammalian blastocyst is analogous to the yolk sac entoderm of lower vertebrates. Several blastocyst stages were examined in the course of my work, but the first recognizable germ cells were observed in the entoderm of $2.6-\mathrm{mm}$. embryos.

Kirkham ('16), from his investigation of the monse, reached a rather unique conclusion in that he believed the oogonia to be direct descendants of the primordial germ cells, and spermatogonia to be descendants of epithelial cells. It seems quite unlikely that the functional germ cells of the two sexes could have different origins within the same species.

Simpkins, among others who oppose the theory of early germ cell segregation, questions the power of germ cells to "set out on a journey over several millimeter's of intervening. tissue, cross barriers and penetrate membranes, become carried away in the blood stream, perishing against obstacles they cannot surmount, until the survivors are at last safe in the fundament of the genital gland." If one merely thinks a moment concerning the general unfolding of the egg into the complex embryo he will realize that the process of development involves a considerable shifting of tissues. Also, there are several specific instances of cell movements during development such as the migration of pigment-forming cells from the neural crest, migration of the cells which form the sympathetic ganglia, ete. Finally, in young mouse embryos of 3 and $3.5 \mathrm{~mm}$. when the germ cells are migrating from the gut entoderm into the genital ridge the distance to be traversed is very short, not several millimeters, but only a small fraction of a millimeter. Thus, I see no reason why a germ cell cannot be carried this short distance by a shifting of the tissue, or by its own power, or by both means. 
Even though there may or may not be an early embryonic segregation of germ cells there is yet to be considered the possible origin of sex cells in later embryonic and in postembryonic life. In many instances this problem has been approached merely from a study of the ovaries during the sexually mature life of the individual and it is becoming more evident to the author that in order to get a clear picture of the problem one must seek the solution by a detailed study from the earliest embryos through to sexual maturity. By far the greatest number of investigators who have attacked this problem in post-embryonic stages have concluded that there is a new formation of ova from the germinal epithelium. Among those who have reached such conclusions from their morphological studies are Arai ('20), Allen ('23), Hartman ('26), Butcher ('27), Hargitt ('30), Stockard ('36), Allen and Creadick ('37), Pliske ('38), Guthrie and Jeffers ('38), Marx ('41), Duke ('41), Schmidt and Hoffman ('41), and Everett ('42). The two general methods by which new ova are believed to arise from the germinal epithelium are by mitosis of epithelial cells which contribute potential ova to the cortex, and by enlargement of epithelial cells in situ and their subsequent movement into the cortex where they form follicles. In either case the conclusion is that the ordinary somatic epithelial cells possess the power to differentiate into ova.

In contrast to the above, Cowperthwaite ('25), Martinovitch ('32), Pincus and Enzmann ('37), and Kingsbury ('38), have concluded from their mamralian studies that there is no new formation of ova from the epithelium. They are of the opinion that the sex cells which are set aside during embryonic differentiation are sufficient to supply those which become functional during maturity.

I find that, in the mouse, during later embryonic life and in post-partum stages up to and including sexual maturity there are cells in the epithelium which contribute ova. It appears, however, that these cells in the epithelium which contribute ova have had their origin from the primordial germ 
cells that migrate into the gonad from the gut entoderm during early embryonic development. The morphological study, although supplying evidence, does not prove this conclusion to be absolutely justifiable. Further evidence will be advanced in the experimental section of this paper where a more extensive discussion will be found.

\section{EXPERIMENTAL OBSERVATIONS}

\section{Peromyscus material}

It is obvious from the different interpretations which have been advanced from morphological findings that the germ cell problem must be attacked by some other means before a final solution can be found. It was felt that an experimental approach to the problem was desirable and in particular that the genital ridge area might be removed from its normal environment in these early stages and transplanted to a favorable medium where growth and differentiation might be observed without contact with the gut and its questionable germ cells. Transplantation of the genital ridge to a favorable site in an adult mouse seemed to offer the best possibilities. Therefore, attempts were made to transfer the embryonic area in question to the kidneys of adult mice, since Buyse ('33), and Nicholas ('33), had found the kidney to be a favorable site for mammalian transplants. For these operations the host mice were anesthetized with sodium pentabarbital, and the hair was removed from the region above the kidney with a barium sulphide depillatory.

Embryos were removed from the uteri, immediately after killing the mother, and placed in Ringer-Locke solution which was kept near the body temperature. Some of the mice from each litter were fixed as controls for determining the degree of development. The rest were placed for dissection in fresh saline solution contained in small dishes, the bottoms of which were covered with a mixture of paraffin and beeswax colored with lamp black. Dissection was carried out under a binocular microscope with iridectomy scissors, sharpened steel needles, 
and very fine forceps, all of which had been carefully sterilized. After removing the ventral body wall the viscera were excised with special care to remove all the gut and as much of the dorsal mesentery as possible. Then the genital ridge area was carefully removed for grafting, together with the immediately adjacent dorsal body wall (fig. 14).

An incision was then made in the body wall of the host just abore the kidney. The kidney was forced outside the body and its capsule slit transversely with iridectomy scissors, after which a small pocket was formed between the capsule and the kidney by the use of a small probe. The excised embryonic material was then placed underneath the kidner capsule by means of a very small spatula. In some cases, two transplants, both of the same stage, were made to a single kidney, one to the anterior and the other to the posterior region. The kidney was then carefully pushed back to its normal position and the incision closed with very fine, 20-day self autolyzable gut. After suturing, the wound was covered with a coat of nitrocellulose dissolved in amyl acetate. The operated mice were kept warm until they had completely recovered from the anesthetic.

From 14 to 18 days after the operation the transplants were removed and treated in the same microtechnical manner as described above (p. 51). In the majority of cases the transplants had grown remarkably well, at least from the standpoint of increase in mass. Histological examination revealed that the epidermis, hair follicles, cartilage and comnective tissue exhibited a marked growth, but that the more vital tissues such as germ cells, reproductive ducts, and mesonephric tissues were almost completely lacking. Twenty-five such transplants were made without favorable results. It was felt that the negative results were due, at least in part, to the lack of affinity between the donor and host tissue. In making the transplants the host was always a litter mate of the donor parent; however, as mentioned above, the mice were mixtures of different supspecies. Thus, it was reasoned that there was 
perhaps sufficient protein difference in the host and donor tissues to prevent proper growth and differentiation of the more vital parts.

\section{Albino mouse material}

Another series of transplants was then made using a strain of albino mice from the stock kept by the University of Michigan Zoology Department. Twenty transplants were made with this strain, but the results were essentially the same as those obtained with Peromyscus. A few transplants did show some development of reproductive tissue, but the results were so variable that they were not at all reliable. Through the course of this series of experiments it was found much better to keep the embryos and excised portions in cold Ringer-Locke solution than in the warm as had been practiced. This is in agreement with Waterman's findings in culturing embryonic rabbit tissue ('33).

The more favorable results obtained from the second series of transplants seemed to indicate that the difference in protein specificity of the mice was a relevant factor in the growth and differentiation of the donor tissue. Thus, a third series of transplants was attempted with another strain of albino mice from Doctor Little's Laboratory at Bar Harbor, Maine which had been inbred for fifty or more generations. With these, inbreeding was carried further, and in all cases the host was a litter mate of the maternal donor.

Table 1 shows the third series of transplants made and the results obtained. Of the thirty-eight transplants made, only one failed to give a differentiation of reproductive ducts and mesonephric tubules. In making these transplants the larger embryos were first used, namely those in which the genital ridge was quite distinct and definitely containing germ cells (figs. 16, 19, 21). Successively younger stages were then used for donors, the smallest being $2.4 \mathrm{~mm}$. in length. A careful study of the controls revealed that all of the embryos from $4 \mathrm{~mm}$. to $11.5 \mathrm{~mm}$. inclusive, had germ cells within the genital 
ridge, and in the older ones the associated ducts had developed in varying degrees. In those from $2.4 \mathrm{~mm}$. to $3.5 \mathrm{~mm}$. inclusive, no germ cells were present in the genital ridge. In $3.5-\mathrm{mm}$. embryos a few germ cells were observed in the lower part of the dorsal mesentery and some within the gut entoderm. In the 3-mm. and younger stages the only discernible germ cells were within the gut. The results revealed that only those

TCABLE 1

Embryonic transplants.

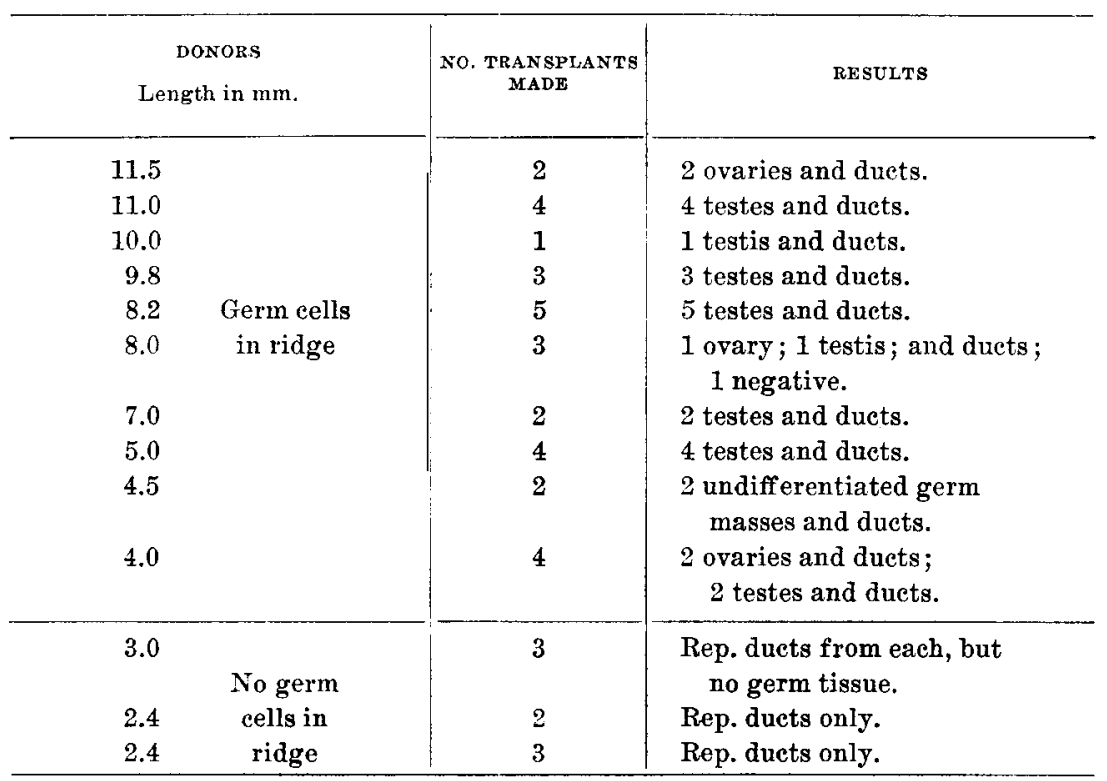

transplants having germ cells within the ridge at the ume of transplantation developed typical gonadal tissue while on the kidney of the host (figs. 17, 18, 20, 22, 24, 25). In general, the degree of gonadal differentiation of the transplants when removed from the host kidney was comparable to the stage of development attained in the intrauterine embryos of the same age. The transplants lacking germ cells within the genital ridge at the time of transplantation never developed any germinal tissue, nor did they develop gonads. However, the 
ducts normally associated with the gonad such as mesonephric tubules and ducts, müllerian ducts, epididymis, etc. were developed in varying degrees (figs. 27, 28). The fact should be stressed that the ducts normally associated with the gonad, developed in the transplants even though sex cells did not develop in those from the 2.4- $\mathrm{mm}$. to $3.5-\mathrm{mm}$. donors. The differentiation of ducts within these transplants clearly indicates that the prospective genital ridge was included in the transplant, and that the duct system is not dependent on the presence of germ cells. The absence of gonadal tissue and reproductive ducts in one of the transplants from the older series may be accounted for by a failure of including the vital region while making the dissection. The $100 \%$ correlation between the absence of germ cells in the genital ridge of the younger embryos at the time of transplantation, as substantiated by controls, and their absence in the differentiated transplant seems to prove definitely that the primordial germ cells originate outside of the genital ridge. The close agreement between the experimental and purely morphological observations show that the cells first observed within the gut, and later in the dorsal mesentery, are the progenitors of the germ cells within the genital ridge.

\section{DISCUSSION OF THE EXPERIMENTAL RESULTS}

The results of the above experiments support the theory that the origin of germ cells in the mouse is extra-gonadal. This investigation is the first and only experimental approach to this problem in mammals, but fortunately a few investigators have attacked the problem experimentally in some of the other vertebrates. Swift's contention that the germ cells in the chick originate outside the gonad has been supported by experimental evidence. Reagan ('16) excised the germ cell crescent, Benoit ('30) irradiated this region with ultraviolet, Dantschakoff ('31) destroyed the crescent by electric cautery, and Willier ('37) isolated the posterior part of the chick embryo from the crescent and transplanted the isolate to the 
chorio-allantoic membrane of a host embryo. These investigators found that in chick embryos, after such treatment, the gonad-forming areas were without germ cells. Kuschakewitsch ('10) found that in the frog when the primordial germ cells were prevented from reaching the genital ridge a sterile gonad developed. However, later in development there was a secondary origin of germ cells within the gonad. Humphrey ('27, '28) reported that in Amblystoma the gonad will develop in the absence of the primordial germ cells, but that the gland is always sterile. All of these authors are in general agreement, with the exception of Kuschakewitsch, that withont the primordial germ cells the gonad fails to produce any definitive germinal tissue. However, there is considerable disagreement regarding the ability of the gonad to develop in the absence of primitive germ cells. As recorded above, Humphrey, Kuschakewitsch, and Willier have shown that a sterile gonad may develop in the absence of germ cells, but Reagan, Benoit and Dantschakoff failed to get gonad differentiation when the gonad-forming area was void of germ cells. Willier is of the opinion that failure of the latter in getting gonad differentiation was due perhaps to the drastic treatment of the embryos.

The results of the present experiments support the work of Reagan, Benoit and Dantschakoff. The transplants from the young stages, which were without germ cells, differentiated mesonephric ducts and tubules, and müllerian ducts, but gonads recognizable as to sex were not formed. The fact that these ducts, normally associated with the gonad, developed is evidence that the prospective urogenital area was included in the transplant. Willier also suggests that Dantschakoff failed to get gonad differentiation because the experimental embryos were not old enough at the time of examination. This criticism cannot be applied to the present experiments on the mouse because all of the transplants were permitted to develop on the host for at least 14 days. Furthermore, differentiation of the reproductive ducts was well marked. In some cases differentiation had progressed within the duct system to such an 
extent that typical uterine tissue, vas deferens, epididymis, etc. were identified. This detailed histological differentiation also demonstrates the compatibility between the donor and host tissue, a factor not to be overlooked in transplantation.

It appears that all who have investigated the germ cell problem experimentally are in general agreement that the primordial germ cells originate outside the gonad, and all agree, with the exception of Kuschakewitsch, that these cells are necessary for the later development of germinal tissue in the gonad. It seems that the conclusions of Kuschakewitsch can justifiably be questioned because of the nature of his work. He reported that the primordial germ cells in the frog failed to become associated with the gonad-forming area as a result of delayed fertilization, and although the gonad was at first sterile, there was later a secondary in-suit formation of germ cells. It would be extremely difficult to determine the source of the secondary germ cells under such circumstances.

The role of the germ cells in the development of the somatic part of the gonad is still questionable and must be investigated further before we can arrive at any definite conclusions. There is certainly a possibility that they may not play an important role in the chick, for example, and yet do so in the mouse, but the lack of agreement among the investigators of the problem in the chick is sufficient to indicate the need for further work.

EXPERIMENTS RELATING TO THE POST-EMBRYONIC DEVELOPMENT OF OVA

The morphological observations above indicate that in the later embryonic and post-embryonic development of the ovary the germinal epithelium is active in forming new ova, and that this formation continues into the period of sexual maturity. This phase of the germ cell problem has received almost as much attention in the past as the early origin of the germ cells ; likewise, there is as much disagreement on the question. Thus, it appears futile to attempt a settlement of this question 
by further morphological observation. For this reason the author has sought by various experimental means to solve the problem.

\section{Regeneration experiments}

It is a well established fact that when a portion of an ovary is removed the remaining part will undergo regeneration. In many cases the vestige will attain a size comparable to the original and become functional. With this in mind a series of young unmated females were subjected to this type of operation. It was hoped that a detailed histological study of the ovary during the regeneration phases might be of value in determining the source of the regenerated tissue. This operation is a very simple one, involving the use of an anesthetic, removal of the hair from the region above the ovary, making a small incision in the body wall, removing a part of the ovary with small scissors, and then closing the incision with suture thread. The mice were killed at intervals following the operation and the ovaries were subjected to the microtechnical methods already described. Contrary to what was expected, no favorable results were obtained. The ovaries exhibited regeneration in varying degrees, but no clues were obtained as to the origin of the respective cells.

\section{Isolation experiments}

A desirable approach to the problem seemed to be to isolate the germinal epithelium from the underlying tissue. This offered three possibilities, namely: 1 . To peel the epithelium from the ovary and transplant it to the kidney for differentiation. 2. To permit the ovary minus its epithelium to differentiate in its normal position. 3. To remove the medullary and cortical elements from the ovary, thus leaving the epithelium within the female. All three attempts were made, but considerable difficulties were encountered. It was almost impossible to remove the epithelium from the ovary and when a portion was removed it was questionable how much of the 
underlying tissue was included. Conversely, it was impossible to be sure that all of the epithelium was removed from the intact gland. Due to these difficulties the results obtained seemed unreliable. It was noted however, that when the epithelium was transplanted it was very frequently destroyed as a result of fusing with the kidney tissue. Thus, another series of transplants was made involving the entire ovary. Some ovaries together with the surrounding bursae were transplanted to the kidney, and in others the bursae were removed before transplantation. These were left on the host from 20 to 30 days. Histological examination revealed that the epithelium of ovaries whose bursae had been removed was almost completely destroyed by fusion with the kidney tissue. In these ova were almost completely lacking, except for a few older follicles in the central region of the transplanted gland. In those which were transplanted with the bursae, the fusion occurred in most instances between the bursa and the kidney, leaving the epithelium free. In these the ovary was almost normal in appearance, revealing numerous small ova immediately beneath the epithelium and follicles in various stages of development within the deeper portions. Figure 29 represents a portion of a transplanted ovary whose epithelium had in part fused with the kidney and was destroyed, and a portion which is normal as a result of the protection given by the bursa. This clearly indicates that young ova and follicles are present beneath the free portion of the epithelium, whereas there is a complete absence of ova beneath the region where the epithelium fused with the host tissue. These results strongly support the view that cells of the epithelium give rise to new ova, and that without the epithelium no ova are formed.

\section{$X$-ray experiments}

Another approach to the problem of the origin of ova in the post-partum stages was by the use of x-rays. Irradiation with $\mathrm{x}$-rays is known to destroy germ cells in the ovary, provided the dosage is high enough (Brambell and Parkes, '27; 
Murray, '31). It was hoped that by using the proper dosage the ovary could be sterilized, and then by studying it microscopically after sterilization it would be possible to determine the source of any new ova which might be formed. It is a well established fact that germ cells are more susceptible to x-rays than ordinary somatic tissue such as the epithelium of the ovary. Thus, it seemed reasonable to assume that should all of the ova be killed, the appearance of any new ova would indicate that they were derived from ordinary somatic cells of the ovary. Conversely, if no new ones formed it should indicate that cells other than the recognized germ cells lack the capacity to form germinal tissue.

Thirty-five mice which ranged in age from 21 to 35 days were irradiated. Figure 30 shows the apparatus that was used to hold the mice during irradiation. It consists of a board to which was attached a thin celluloid sheet arranged in folds to accommodate the various sizes of mice. Two or three mice could be placed beneath each fold and by placing cotton between the animals they could be held immovable. The mice were covered with lead shields having a hole large enough to expose the region above the gonads, thus minimizing the effect of the irradiation on the other organs.

Table 2 gives the pertinent data regarding each mouse irradiated, such as age, milliamperage, voltage, distance from the target, time in minutes, dosage in $r$ units, days after irradiation until the animal was killed, and the general condition of the ovaries. By varying the dosage and by killing the mice at intervals following irradiation a good series was obtained. It was found that $168 \mathrm{r}$ units were necessary to sterilize the ovary; thus, most of the mice were given that dose or more. Four of the animals, C 5, C 6, C 7 and C 8, were irradiated twice, each was given $200 \mathrm{r}$ units at 35 days of age, and 115 days later they were given 224 units. Except for a short period immediately after irradiation none of the mice exhibited any signs of detrimental effect from the treatment. A few were rather sluggish for a short time after 
TABLE 2

$X$-ray series.

\begin{tabular}{|c|c|c|c|c|c|c|c|c|}
\hline so. & $\begin{array}{l}\text { AGH IN DAYS } \\
\text { WHEN } \\
\text { IRRADIATED }\end{array}$ & M.A. & $\mathrm{v}$ & DIST. & $r$ & DOSAGE & $\begin{array}{l}\text { DAYS FROM } \\
\text { IRRADIA- } \\
\text { TION TO } \\
\text { DRATH }\end{array}$ & OBSERVATIONS \\
\hline & & & & inches & & & & \\
\hline$A 1$ & 30 & 10 & 85 & 36 & 11 & $154 \mathrm{r}$ & 3 & Normal. \\
\hline A 2 & 30 & 10 & 85 & 36 & 11 & $154 \mathbf{r}$ & 8 & $\begin{array}{l}\text { Disintegrating } \\
\text { follicles. }\end{array}$ \\
\hline A 3 & 30 & 10 & 85 & 36 & 11 & $154 \mathrm{r}$ & 10 & Almost normal. \\
\hline A 5 & 30 & 10 & 85 & 36 & 11 & $154 r$ & 34 & Very few follicles. \\
\hline A 6 & 30 & 10 & 85 & 36 & 11 & $154 \mathbf{r}$ & 45 & Luteinized. \\
\hline B 1 & 21 & 10 & 85 & 18 & 3 & $168 \mathrm{r}$ & 21 & Tubular structures. \\
\hline B 2 & 21 & 10 & 85 & 18 & 3 & $168 \mathrm{r}$ & 21 & $\begin{array}{l}\text { Tubular structures; } \\
\text { few follicles. }\end{array}$ \\
\hline B 3 & 21 & 10 & 85 & 18 & 3 & $168 \mathrm{r}$ & 54 & Tubular structures. \\
\hline B 4 & 21 & 10 & 85 & 18 & 3 & $168 \mathrm{r}$ & 85 & Numerous tubules. \\
\hline B 5 & 21 & 10 & 85 & 18 & 3 & $168 \mathrm{r}$ & 85 & Numerous tubules. \\
\hline C 1 & 35 & 5 & 117 & 18 & 5 & $200 \mathbf{r}$ & 22 & $\begin{array}{l}\text { Degenerate } \\
\text { follicles. }\end{array}$ \\
\hline $\mathrm{C} 2$ & 35 & 5 & 117 & 18 & 5 & $200 \mathrm{r}$ & 59 & Luteinized. \\
\hline C 3 & 35 & 5 & 117 & 18 & 5 & $200 \mathbf{r}$ & 60 & $\begin{array}{l}\text { Num. cords \& } \\
\text { tubules. }\end{array}$ \\
\hline $\mathrm{C} 4$ & 35 & 5 & 117 & 18 & 5 & $200 \mathbf{r}$ & 63 & Few tubules. \\
\hline \multirow[t]{2}{*}{$\mathrm{C} 5$} & 35 & 5 & 117 & 18 & 5 & $200 \mathbf{r}$ & & Tubular strueture \\
\hline & 150 & 10 & 85 & 18 & 4 & $224 \mathrm{r}$ & 125 & Aecentuated. \\
\hline \multirow[t]{2}{*}{$\mathrm{C} 6$} & 35 & 5 & 117 & 18 & 5 & $200 \mathbf{r}$ & & Tubular structure \\
\hline & 150 & 10 & 85 & 18 & 4 & $224 \mathbf{r}$ & 155 & Aecentuated. \\
\hline \multirow[t]{2}{*}{ C 7} & 35 & $\bar{\delta}$ & 117 & 18 & 5 & $200 \mathrm{r}$ & & $\begin{array}{l}\text { Num. tubules, } \\
\text { vaseular \& epith. }\end{array}$ \\
\hline & 150 & 10 & 85 & 18 & 4 & $224 \mathrm{r}$ & 176 & ingrowths. \\
\hline \multirow[t]{2}{*}{ C 8} & 35 & 5 & 117 & 18 & 5 & $200 \mathbf{r}$ & & $\begin{array}{l}\text { Num. cords, tubes, } \\
\text { and epith. }\end{array}$ \\
\hline & 150 & 10 & 85 & 18 & 4 & $224 \mathrm{r}$ & 188 & ingrowths. \\
\hline $\mathrm{D} 1$ & 27 & 5 & 117 & 18 & 5 & $200 \mathbf{r}$ & 16 & Normal. \\
\hline $\mathrm{D} 2$ & 27 & 5 & 117 & 18 & 5 & $200 \mathrm{r}$ & 20 & Luteinized. \\
\hline D 3 & 27 & 5 & 117 & 18 & 5 & $200 \mathrm{r}$ & 103 & $\begin{array}{l}\text { Degenerate } \\
\text { follicles. }\end{array}$ \\
\hline D 4 & 27 & 5 & 117 & 18 & 5 & $200 \mathrm{r}$ & 106 & Numerous tubules. \\
\hline D 5 & 27 & 5 & 117 & 18 & 5 & $200 \mathbf{r}$ & 122 & Similar to testis. \\
\hline D 6 & 27 & 5 & 117 & 18 & 5 & $200 \mathrm{r}$ & 150 & Similar to testis. \\
\hline E 1 & 31 & 10 & 85 & 18 & 3 & $168 \mathbf{r}$ & 5 & Almost normal. \\
\hline E 2 & 31 & 10 & 85 & 18 & 3 & $168 \mathrm{r}$ & 31 & Luteinized. \\
\hline E 3 & 31 & 10 & 85 & 18 & 3 & $168 \mathrm{r}$ & 34 & Few tubules. \\
\hline E 4 & 31 & 10 & 85 & 18 & 3 & $168 \mathrm{r}$ & 91 & Numerous tubules. \\
\hline E 5 & 31 & 10 & 85 & 18 & 3 & $168 \mathrm{r}$ & 121 & Numerous tubules. \\
\hline E 6 & 31 & 10 & 85 & 18 & 3 & $168 \mathrm{r}$ & 136 & $\begin{array}{l}\text { Numerous tubules; } \\
\text { vascular. }\end{array}$ \\
\hline E 7 & 31 & 10 & 85 & 18 & 3 & $168 \mathrm{r}$ & 136 & Epith. ingrowths. \\
\hline F 1 & 21 & 10 & 85 & 18 & 4 & $224 \mathrm{r}$ & 90 & $\begin{array}{l}\text { Few tubes and } \\
\text { cords. }\end{array}$ \\
\hline $\mathbf{F} 2$ & 21 & 10 & 85 & 18 & 4 & $224 \mathrm{r}$ & 90 & Numerous tubules. \\
\hline F 3 & 21 & 10 & 85 & 18 & 4 & $224 \mathbf{r}$ & 90 & Numerous tubules. \\
\hline $\mathbf{F} 4$ & 21 & 10 & 85 & 18 & 4 & $224 \mathbf{r}$ & 90 & Epith. ingrowths. \\
\hline
\end{tabular}


removal from the apparatus, which was probably a result of their close confinement.

The ovaries which were removed from 3 to 21 days after irradiation contained follicles in various stages of degeneration. A few young follicles appeared normal, but there was no evidence of a new formation of ova.

Ovaries from those which received 168 or more $r$ units and were killed after 21 days following irradiation were definitely abnormal and without ova. Figure 31 shows an ovary from a female receiving $168 \mathrm{r}$ units at 21 days post-partum and killed 85 days after irradiation. The gland is filled with tubular structures, the cells of which are epithelioid in appearance, except some which are luteinized. There is a complete absence of any cells that resemble ova. In general the gland resembles an ovo-testis.

A portion of an ovary from an animal receiving $200 \mathrm{r}$ units at 27 days p.p. and killed 122 days after irradiation is shown in figure 32. The general structure is the same as that described above, but the tubular condition is more accentuated. Some of the cells within the tubes and cords appear somewhat like cells normally found in the sex cords of a young testis.

Figure 33 shows a portion of an ovary receiving $424 \mathrm{r}$ units, 200 at 35 days p.p. and 224 units more 125 days later. This specimen was killed 188 days after the first irradiation. The epithelium of this gland, which is typical of several receiving. a high dosage of $x$-rays, is invaginated at numerous places. At the terminal portion of the deeper ingrowths are cells which simulate those found in the cordlike structures throughout the gland. These ingrowths resemble the so-called Pflüger's tubes, except they lack ova. However, it is possible to homologize them with the ingrowth of sex cords in the developing testis. In any event the ovaries from the irradiated animals appear more like young testes than like normal ovaries. It is possible that the peculiar cord and tubular structures are anovular follicles, the ovum having been killed by the $\mathrm{x}$-rays. The cords are continuous through many sections and are 
usually composed of one or two layers of cells. However, the cells within are much larger than normal follicular cells.

The evidence is suggestive of sex-reversal, but no typical male sex cells have been observed in any of the irradiated ovaries. If any of the cells within the cords were potential sperm cells they should have continued to develop and transform since some of the mice were kept 5 and 6 months after irradiation.

These results are believed to be quite applicable in connection with the problem of the origin of ova in the post-partal ovary. The absence of any sex cells within the ovary after irradiation favors the view that no new ova are formed from the ordinary epithelial cells. It is certain that all typical ova were killed in those mice receiving 168 or more $r$ units, and no new ones were formed, and it is also certain that the somatic epithelial cells of the ovary continued to be viable. If it is true that any ovarian epithelial cell of the normal ovary possesses the capacity to form ova it seems that this capacity should be retained after irradiation because it has been demonstrated that epithelial cells continue to be viable after irradiation.

\section{Discussion}

Various attempts have been made to solve the question regarding germ cell origin in adult animals. The majority who have approached the problem experimentally have sought the solution by removal of the adult gonad and after a lapse of time observing the site of removal for any sign of regenerated germinal tissue. Davenport ('25) found after what he believed to be a complete removal of ovaries in mice that there was regeneration of germinal tissue. He concluded from this that somatic tissue could transform into germ cells. Parkes, Fielding and Brambell ('27) removed the ovaries, capsules and portions of the tubes from 121 mice. The oestrus cycle ceased in eleven of the animals for a long period after the operation, but vaginal changes characteristic of oestrus later began in all of the eleven animals. Histological study of 
the extirpated ovaries revealed that removal was complete; however, the renewal of the vaginal changes was evidence that new ovarian tissue was present. Ovarian tissue was demonstrated histologically in eight of the eleven mice, thus they concluded that the regenerated tissue was of somatic origin. Hooker and Cunningham ('38) found that after bilateral removal of the testis in the fowl some of the animals subsequently regenerated testicular tissue. Occasionally cords were seen forming from the peritoneum in a manner similar to that followed in the embryo; thus, they concluded that somatic cells can transform into germ cells.

Haterius ('28) removed both ovaries from ninety-six mice. In these there were a few cases of regeneration which were believed to be due to a failure of complete removal. Haterius concluded that germinal tissue in mice will not arise de novo from the coelomic epithelium following ovariectomy. He found that complete bilateral castration was invariably followed by atrophy of the genitalia and the tubes and uteri were found to be small and anemic. Heys ('31) found from her study of ovarian regeneration in rats that after complete removal of the ovaries there was no new formation of germinal tissue. Her experiments showed that the age of the animals at the time of removal was the determining factor since none of the young animals regenerated ovarian tissue, while some of the older ones did. This she believed to be due to the fact that complete removal of the gland could be accomplished in the young mice whereas it was very difficult in the older animals.

Thus, we see that the results of such experiments are not too reliable in solving the fundamental problem because of the difficulties encountered in complete removal of all the gonadal fragments. I encountered comparable difficulties in attempting to isolate the germinal epithelium from the cortical region of the ovary so I felt that the results obtained were not sufficiently reliable to report.

Long ('41) isolated the germinal epithelium from the ovary of the mouse and cultured the isolate. From the cells in the 
epithelium he observed the development of ova, some of which developed into primary follicles. This would appear to be an ideal approach to the problem, but here again it seems that it would be extremely difficult to be certain that the epithelium was free of all germ cells that might be adhering since the germ cells in a sense are located among the epithelial cells.

My series of ovarian transplants, with and without the bursa, made to the kidney shows definitely that when the germinal epithelium is destroyed by fusion with the kidney tissue there is a lack of ova formation beneath the fused portion. This appears to be good evidence that no new ova may form in the post embryonic ovary without the germinal epithelium.

My results from irradiating the ovaries is comparable to that of Brambell, Parkes, and Fielding ('27). They, too, observed that after irradiation there was a proliferation of cords from the epithelium which resembled the so-called spermatic cords. However, these authors intimate that some cells from these proliferations may be ovular follicles. My observations show that these peculiar ingrowths are indicative of a possible trend toward sex reversal, but no identifiable sex cells have been observed in the cords. The most significant results from the $x$-rayed series are, that once all the germinal tissue is destroyed there is no new formation of ova. This seems to prove that the somatic epithelial cells do not possess the capacity to form ova.

We have seen from the embryological series that there is an early segregation of germ cells, these are first observable in the gut and subsequently migrate from the gut entoderm into the sphanchnic mesoderm and through the dorsal mesentery into the genital ridge. Here some of the germ cells become lodged between the somatic cells of the epithelium. By isolating the genital ridge, before the germ cells are found therein, and transplanting it to the kidney of an adult it has been demonstrated that a gonad with sex cells will not form. This substantiated the morphological observations that seggregation does occur. From the morphological study of the 
post embryonic development of the ovary, and from transplantation of the ovary to the kidney it appears that the ova arise from cells in the epithelium. The results from the $x$-rayed ovaries indicate that once the sex cells within the ovary are destroyed there is no new formation of ova from the epithelium. In view of these facts I feel that the only logical conclusion to draw is, that the sex cells which are set aside in early development are the only ones that form ova. Those which are set aside early and are lodged in the epithelium are the ones which periodically form ova, and since they are among the epithelial cells it appears that new ova are not derived from somatic cells but from the primordial germ cells. I believe that further study of the earliest embryos through to sexual maturity will reveal these conclusions to be true in other forms. Purely morphological observations have led to conflicting views in the past; thus, the necessity of supplementing the morphological findings with experimental study.

In many instances I have found enlarged cells within the germinal epithelium which are without doubt potential ova. However, in no instance have I found such a cell to be actually a part of the peritoneal membrane. The cells of the peritoneum are stretched considerably and form a very thin membrane over the outer surface of these enlarged cells (figs. 5, 11). I feel that the difficulty encountered in observing the relation of the enlarged cells to the epithelium has been chiefly responsible for the conflicting opinions concerning the problem of the origin and differentiation of germ cells.

\section{SUMMARY AND CONCLUSIONS}

1. A morphological study of a series of Peromyscus and albino mouse embryos shows that the primordial sex cells are set aside early. The germ cells were first found in the gut entoderm of 2.6 -mm. embryos.

2. From the gut the cells migrate into the splanchnic mesenchyme and through the dorsal mesentery into the genital ridge. 
3. Once within the genital ridge, some of the germ cells become located among the somatic cells of the epithelium. The ova which form in post-embryonic development are derived from these cells which enlarge in situ and then migrate into the cortex of the ovary.

4. Some cells are added to the cortex by mitosis of cells in the epithelium, but it is not certain from morphological evidence that such cells form ova.

5. The follicular cells arise from the epithelial cells which are carried into the cortex with the enlarged oocytes.

6. The theca cells arise from stroma cells represented by the septulae and tunica albuginea.

7. Transplants of the genital ridge to a host kidney before sex cells are found therein will not form sex cells, although the associated reproductive and mesonephric ducts will develop.

8. Transplants of the genital ridge after the sex cells are located within it will form typical testicular or ovarian tissue. Thus, without the primordial sex cells derived from those first found in the gut, no sex cells will develop.

9. Transplants of the ovaries of young mice to the kidney of adult animals show that when the germinal epithelium is destroyed as a result of fusion with the kidney tissue there is a cessation in the formation of new ova. If the bursa is included with the ovarian transplant, the germinal epithelium often remains intact, and a proliferation of ova continues from cells in the epithelium.

10. The ovaries of mice receiving 168 or more $r$ units of $x$-ray were sterile. In these the epithelium continued to proliferate, but the ingrowth lacked sex cells. The results show that once all the oogonia are destroyed within the ovary there is no new formation of ova.

11. The majority of the $\mathrm{x}$-raved ovaries simulated an ovotestis; hence, something similar to sex reversal is suggested.

12. Morphological and experimental evidence combine to show that the cells in the epithelium which form ova during 
post-embryonic life are derived from the primordial germ cells which were set aside during early embryonic development. However, these germ cells are in such close relation to the somatic epithelial cells that morphologically it is difficult to differentiate between the two.

\section{LITERATURE CITED}

ALLex, B. M. $190+$ The embryonic development of the ovary and testis of mammalia. Am. J. Anat., vol. 3, pp. 89-155.

AlLeN, EdGar 1923 Ovogenesis during sexual maturity. Am. J. Anat., vol. 31, pp. 439-482.

AlleN, EdgAR, AND R. N. CREADICK 1937 Ovogenesis during sexual maturity. Anat. Rec., vol. 69, p. 191.

ARAl, Hayato 1920 On the postnatal development of the ovary (albino rat) with especial reference to the number of ova. Am. J. Anat., vol. 27, pp. 405-462.

Bnolt, J. 1930 Destruction des gonocytes primaires dans le blastoderme du poulet par les rayons ultraviolets, aux premiers states du développement embryonnaire. Proe. 2nd Int. Congress for Sex Research, pp. 162-170.

Bookнout, Cazly G. 1937 The germ cell cycle in the guinea pig. I. The embryonic development of the testis. II. The postnatal development of the testis. Zeitschr. Zellforsch. u. mikrosk. Anat., vol. 25, pp. $728-763$.

Braxbell, F. W. Rogers 1927 The development and morphology of the gonads of the mouse. I. The morphogenesis of the indifferent gonad and of the ovary. Proc. Roy. Soc. (London) B 101, pp. 391-408.

Brambfil, F. W. R., A. S. Parkes and Una Fielding 1927 Changes in the ovary of the mouse following exposure to $x$-rays. Proc. Roy. Soc. (London) B 101, pp. 29-55, 95-114.

BUTCHER, EARL O. 1927 The origin of the definitive ova in the white rat (Mus norvegicus albinus). Anat. Rec., vol. 37, pp. 13-29.

BUYSE, ADRIAN 1933 The transplantation of embryonic mammalian primordia. Anat. Rec., vol. 55, p. 10.

Cow PERThwaite, MaRIoN HAzE, 1925 Observations of pre- and post-pubertal oögenesis in the white rat, Mus norvegicus albinus. Am. J. Anat., vol. 36, pp. 69-90.

Dantschakorf, W., W. Dantschakom, JR., and L. Bereskina 1931 Keimzelle und Gonade. I A. Identität der Wanderzellen und der entodermalen Wanderzellen. Experimentelle Beweise. Zeit. f. Zellforsch. u. mikr. Anat., Bd. 14, S. 323-375.

DantschaKoFr, W. 1932 Keimzelle und Gonade. II b. Ganzheit des Gewebekomplexes als Faktor in der Entwicklung der Gonade. Zeit. f. Zellforsch. u. mikr. Anat., Bd. 15, S. 581-644.

DAvenport, C. B. 1925 Regeneration of ovaries in mice. J. Exp. Zool., vol. 42, pp. 1-11. 
Duke, KenNeTH L. 1941 The germ cells of the rabbit ovary from sex differentiation to maturity. J. Morph., vol. 69, pp. 51-81.

EverEIT, N. B. 1942 The origin of ova in the adult opossum. Anat. Rec., vol. 82 , pp. 77-91.

FIRKET, JEAN 1920 On the origin of germ cells in higher vertebrates. Anat. Rec., vol. 18, pp. 309-316.

Fuss, A. 1913 Über die Geschlechtszellen des Menschen und der Säugetiere. A reh. mikrosk. Anat., vol. 81, pp. 1-23.

Guthrie, Mary J., and Katharine R. Jempers 1938 A eytological study of the ovaries of the bats Myotis lucifugus lucifugus and Myotis griesescens. J. Morph., vol. 62, pp. 523-556.

HaRgiTT, G. T. 1925 The formation of the sex glands and germ cells of mammals. $K$. The origin of the germ cells in the albino rat. J. Morph. and Physiol., vol. 40, pp. 517-558.

1930 The formation of sex glands and germ cells of mammals. III. The history of the female germ cells in the albino rat to the time of sexual maturity. J. Morph. and Physiol., vol. 49, pp. 277-331.

Hartman, Cari, G. 1926 Postpubertal oögenesis in the opossum. Anat. Rec., vol. 32 , p. 209.

Haterius, H. O. 1928 An experimental study of ovarian regeneration in mice. Physiol. Zool., vol. 1, pp. 45-54.

Heys, FloRence 1931 The problem of the origin of germ cells. Quart. Rev. Biol., vol. 6, pp. 1-45.

Hooker, Charles W., AND Bert CUnNingham 1938 Regeneration of testis in the fowl and its bearing on the germ cell theory. Anat. Rec., vol. 72, p. 371 .

Humphrer, RUFus R. 1927 Extirpation of the primordial germ cells of Amblystoma; its effect upon the development of the gonad. J. Exp. Zool, vol. 49 , pp. $363-399$.

1928 The developmental potencies of the intermediate mesoderm when transplanted into ventrolateral sites in other embryos; the primordial germ cells of such grafts and their role in development of the gonad. Anat. Ree., vol. 40, pp. 67-101.

KingerY, H. M. 1917 Oögenesis in the white mouse. J. Morph. and Physiol., vol. 30, pp. 261-315.

Kingsbury, B. F. 1938 The post-partum formation of egg eells in the cat. J. Morph., vol. 63, pp. 397-419.

KIRKHAM, W. B. 1916 The germ cell cycle in the mouse. Anat. Rec., vol. 10, pp. 217-219.

KuschaKewitsch, S. 1910 Die Entwicklungsgeschichte der Keimdrüsen von Rana esculenta. Festschrift f. R. Hertwig, Bd. 2, S., 61-224.

LoNG, J. Herman 1941 Growth in vitro of ovarian germinal epithelium. Carnegie Inst. Wash. Pub. 518. Contrib. to Embryology, vol. 28, pp. 170-178.

Martinovitch, P. 1932 L'ovogenèse post-natale chez les Mammifères (Lapins, Brebis). Compt. Rend. Soc. Biol., vol. 110, pp. 502-504.

MARX, LoRE 1941 Replacement of oöcytes in the ovary of normal and hormone injected young rats. Anat. Rec., vol. 79, pp. 115-131. 
Nicholas, J. S. 1933 The development of rat embryonic tissue after transplantation of the egg to the kidney. Anat. Rec., vol. 55, p. 31.

Parkes, A. S., Una Fielding and F. W. R. Brambeli 1927 Ovarian regeneration in the mouse after complete double ovariotomy. Proc. Roy. Soc. (London) B vol. 101, pp. 328-354.

Pincus, G., and E. V. Enzmann 1937 The growth, maturation and atresis of the ovarian eggs of the rabbit. J. Morph., vol. 61, pp. 351-384.

PLISKE, E. C. 1938 The follieular eycle in the sexually mature thirteen-lined ground squirrel (Citellus tridecemlineatus Miteh.), J. Morph., vol. 63, pp. $263-287$.

RAUH, WaLter 1926 Ursprung der weiblichen Keimzellen und die chromatischen Vorgänge bis zur Entwicklung des Synapsisstadiums. Beobachtet an der Ratte (Mus. decum. alb.). Zeitsehr. f. Anat. u. Entwgseh.. Bd. 78 , S. 637-668.

REAGAN, F. P. 1916 Some results and possibilities of early embryonic castration. Anat. Rec., vol. 11, pp. 251-267.

RubaschKin, W. 1908 Zur Frage von der Entstehung der Keimzellen bei Säugetierembryonen. Anat. Anz., vol. 32, pp. 222-224. 1909 Über die Urgeschlechtszellen bei Säugetieren. Anat. Hefte., Bd. 39 , S. 603-652.

Schmidt, IDA G., AND F. G. Hofrman 1941. Proliferation and ovogenesis in the germinal epithelium of the normal mature guinea pig ovary, as shown by the colehicine technique. Am. J. Anat., vol. 68, pp. 263-273.

Simpkins, C. S. 1923 Origin and migration of the so-called primordial germ cells in the mouse and rat. Acta Zool., vol. 4, pp. 241-278.

Stock ARd, AlmRed H. 1936 Studies on the female reproduetive system of the prairie dog, Cynomys leueurus. II. Normal cyclic phenomena of the ovarian follicles. Pap. Mich. Acad. Science Arts and Letters, vol. 22, pp. 671-690.

Vanneman, AimeE S. 1917 The early history of the germ cells in the armadillo, Tatusia novemeineta. Am. J. Anat., vol. 22, pp. 341-363.

WATERMAN, A. J. 1933 Development of young rabbit blastocysts in tissue culture and in grafts. Am. J. Anat., vol. 53, pp. 317-347. 1939 Survival of rabbit embryonic tissues after removal from the uterus and exposure to low temperature. Anat. Rec., vol. 73, pp. 243.

WILLIER, B. H. 1937 Experimentally produced sterile gonads and the problem of the origin of germ cells in the chick embryo. Anat. Rec., vol. 70, pp. 89-112. 
PLATES 
PLATE 1

EXPLANATION OF FIGURES

1 Section through the posterior region of a $2.6-\mathrm{mm}$. embryo.

2 An enlargement from the gut region of figure 1. A primordial germ cell is shown in the gut entoderm.

3 A germ cell, highly magnified, from the gut entoderm of a 2.6-mm. embryo.

4 Part of the dorsal mesentery from a $4.3-\mathrm{mm}$. embryo.

5 A portion of the genital ridge from a 4.3- $\mathrm{mm}$. embryo. Two germ cells have assumed a position among the epithelial cells.

6 The urinogenital region of a $7-\mathrm{mm}$. embryo.

\section{ABBREVIATIONS}

B.M., Basement membrane G.C., Germ cell 

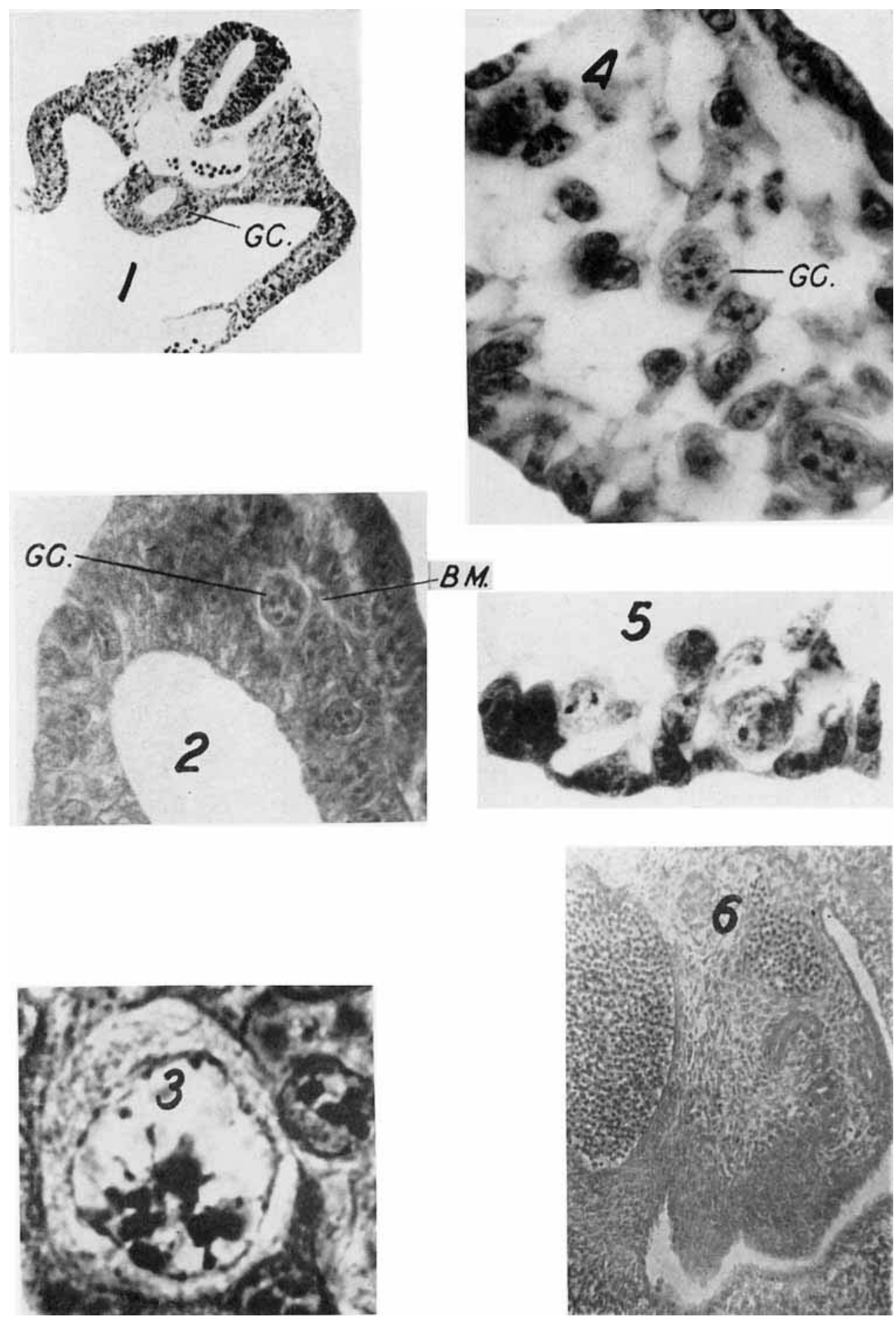
PLATE 2

\section{EXPLANATION OF FIGURES}

7 The ventro-mesial portion of the gonad from a 9 -mm. embryo. Several germ cells are visible.

8 Section of an ovary from a 4-day mouse (p.p.).

9 The cortical region of the ovary from a 7-day mouse. An epithelial cell is seen in division.

10 Ovary from an 11-day mouse.

11 Cortical region of the ovary from a 13-day mouse. 

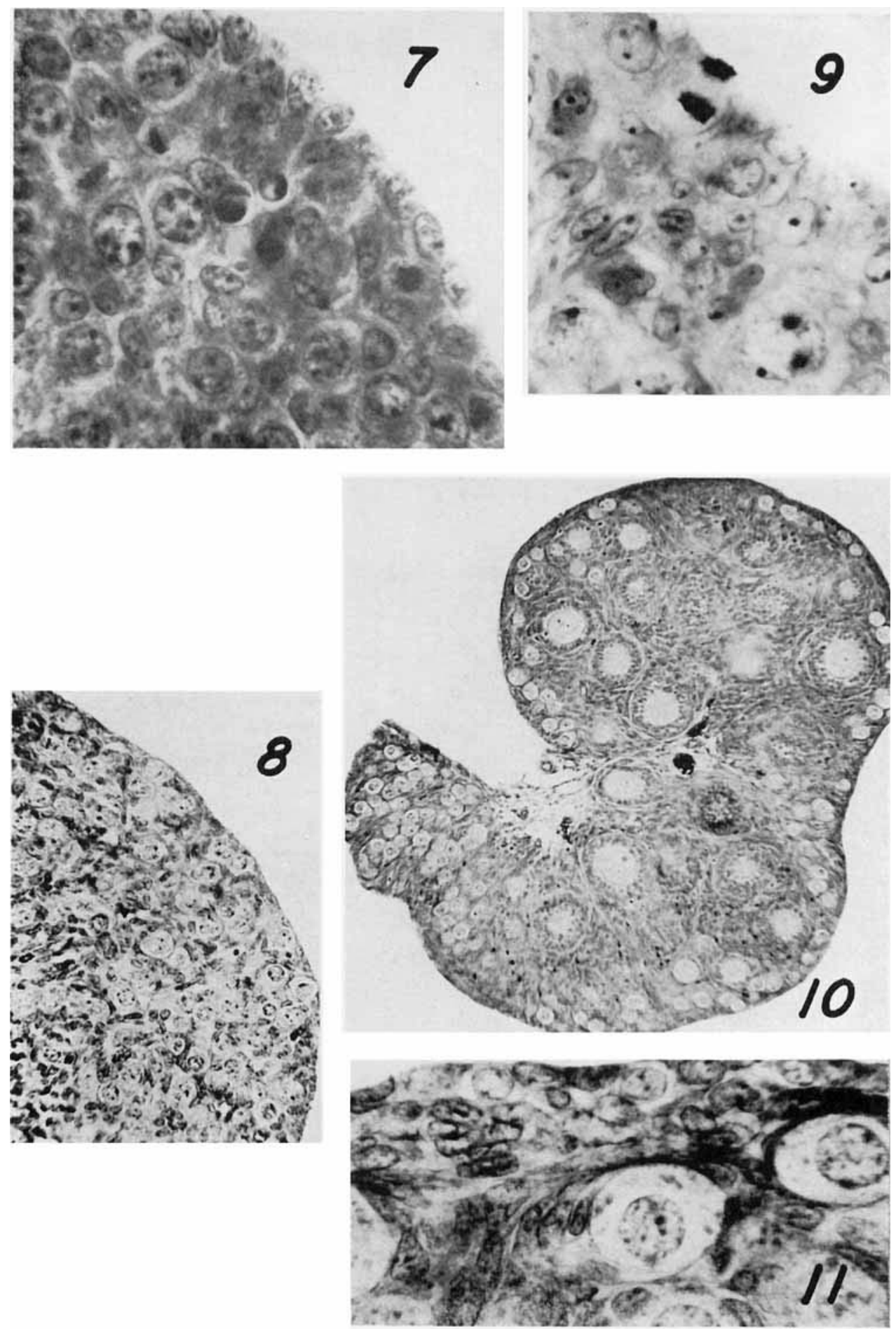
PLATE 3

EXPLANATION OF FIGURES

12 Portion of an ovary from a 17-day mouse.

13 Section of an ovary from a 23-day mouse. Most of the follicles are atretic.

14 This figure shows the region of the embryos that was transplanted.

15 Kidney with two transplants exposed. This photograph was made 14 days following transplantation.

16 Section of a $9.8 \mathrm{~mm}$. embryo, one of the controls in the experimental series.

ABBREVIATIONS

AD., Adrenal gland TR., Region transplanted UG., Undifferentiated gonad 

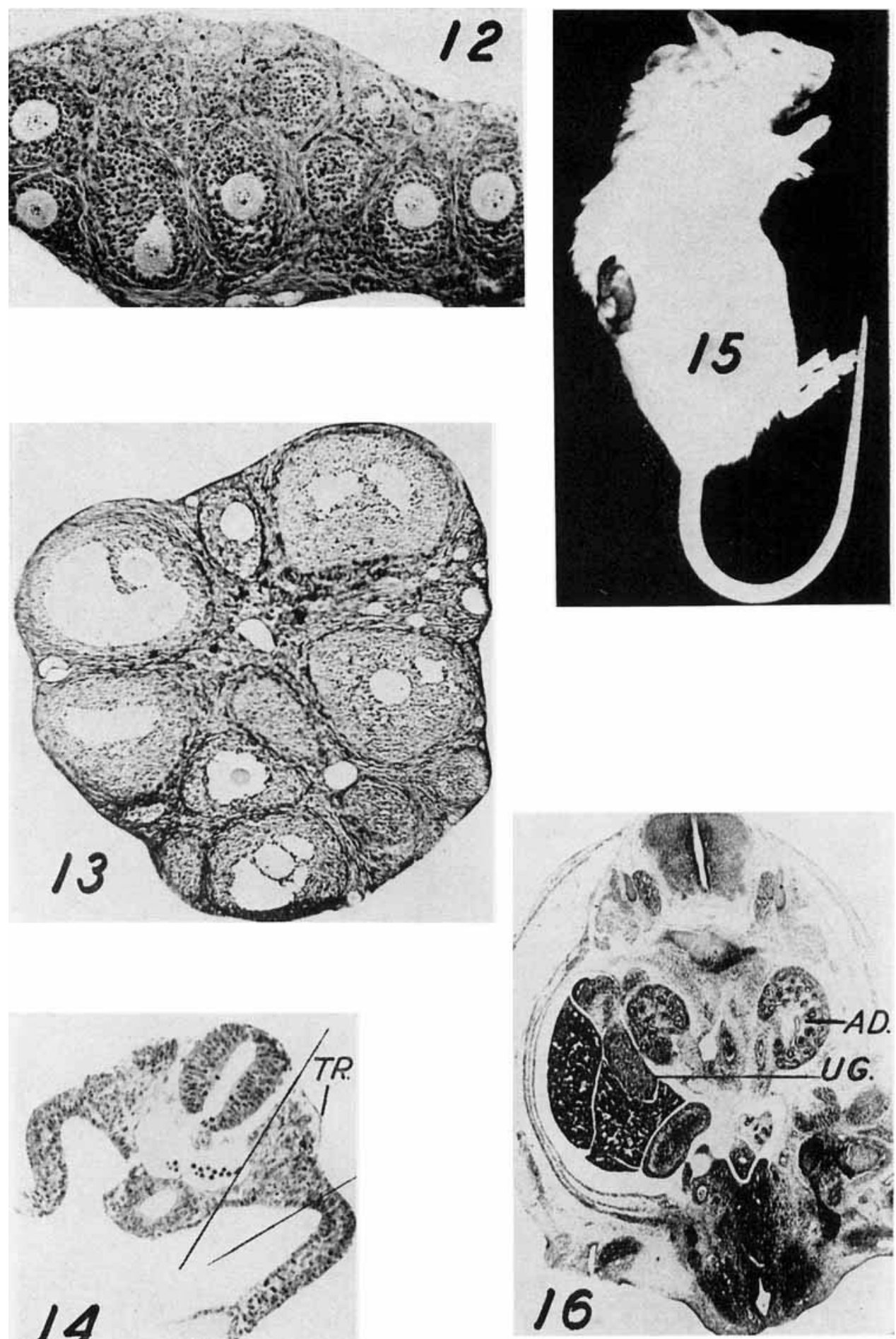


\section{PLATE 4}

\section{EXPLANATIION OF FIGURES}

It Testis on the kidney of a host. Transplant was the urinogenital area of a 9.8-mm. embryo. The host was killed 14 days after the transplant was made.

18 Ovarian tissue on the kidney which differentiated from the transplant made from a 9.8-mm. embryo. (18 days after transplantation.)

19 Fight millimeter control embryo.

20 Testis on the kidney. Transplant from a 8-mm. embryo. (20 days after transplantation.)

21 Five millimeter control enbryo.

22 Testis on the kidney. Transplant made from a 5-mm. embryo. (19 days after transplantation.) 

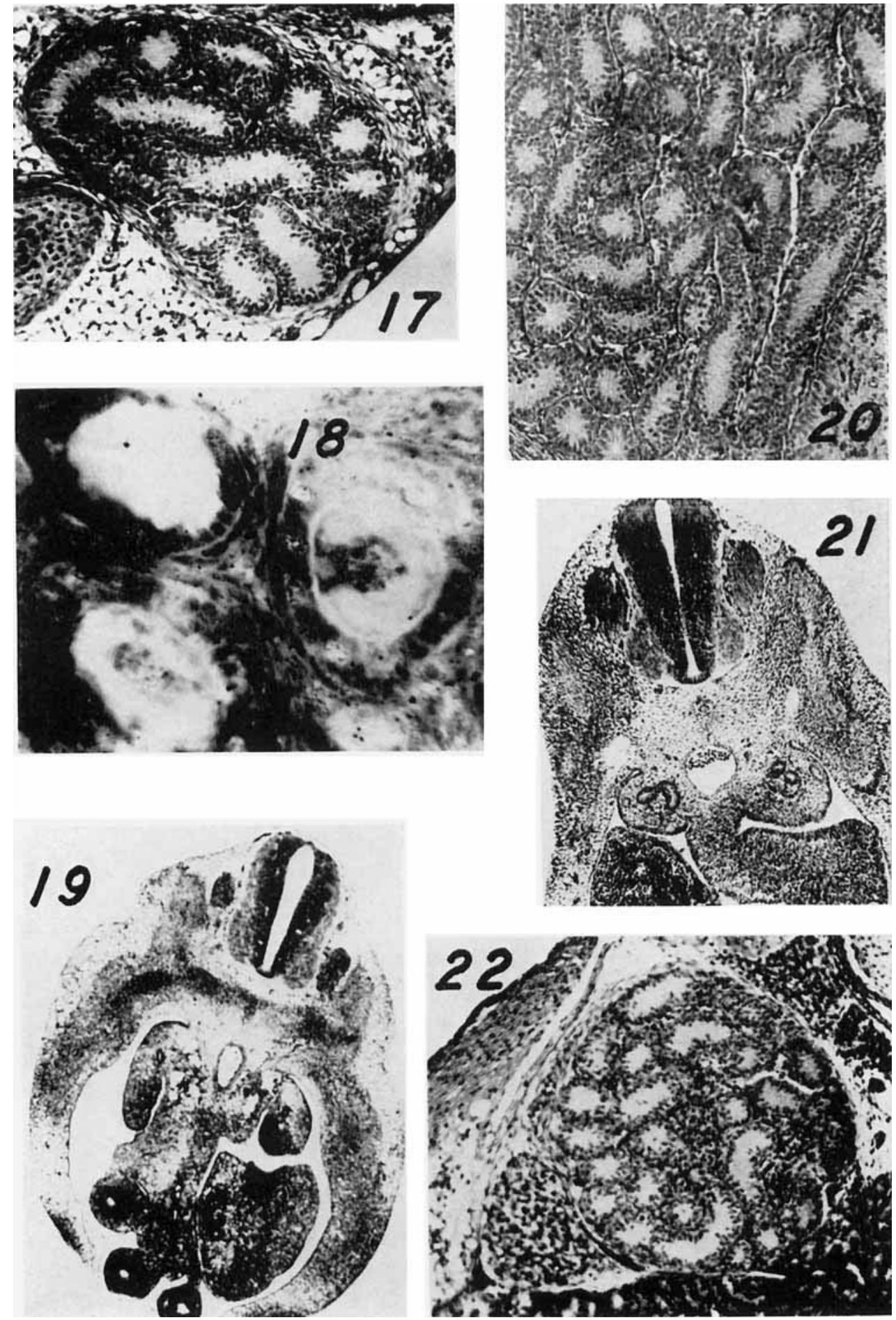
PLATE 5

EXPLANATION OF FIGURES

23 Four millimeter control embryo.

24. Ovarian tissue on the kidney. Transplant was from a 4-mm. embryo. ( 21 days after transplantation.)

25 Undifferentiated germinal tissue and associated ducts on the kidney of a lost animal. This transplant was from a $4.5-\mathrm{mm}$. embryo. (14 days after transplantation.)

26 Two and four-tenths millimeter control embryo.

27 Transplant on the kidney which shows part of the oviduet and mesonephric tubules. Transplant was made from a $2.4-\mathrm{mm}$. embryo. (18 days after transplantation.)

28 Mesonephric duct which developed from a transplant made from a 3-mm. embryo. No germinal tissue developed. (14 days after transplantation.)

\section{ABBREVIATIONS}

(xT., Germinal tissue MT., Mesonephric tubule O., Oviduet 

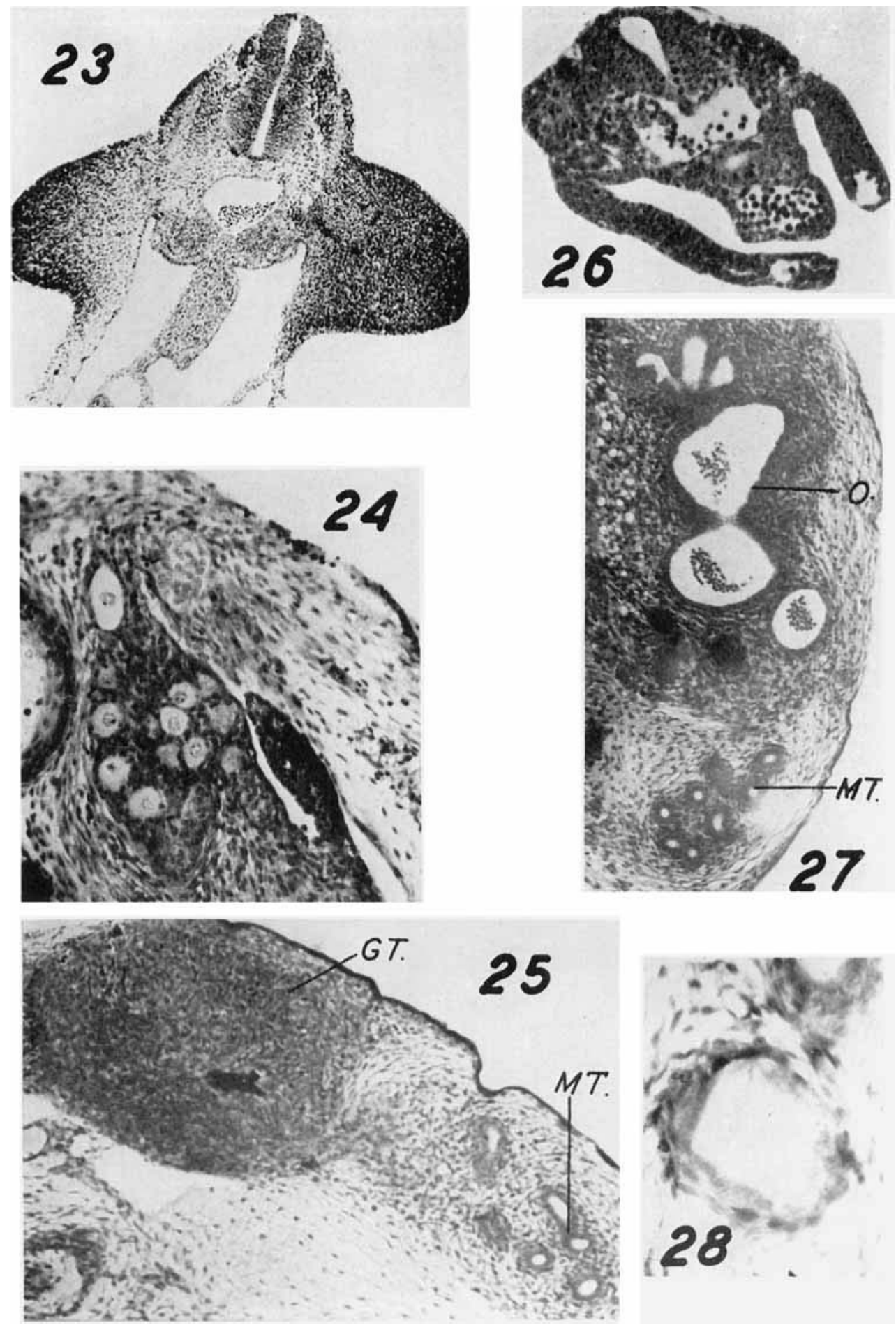
PLATE 6

EXPLANATION OF FIGURES

29 Ovarian transplant from the kidney of an adult mouse. Typical young follicles are observable beneath the intact germinal epithelium, whereas there is an absence of ova beneath the epithelium which has fused with the kidney tissue.

30 Apparatus which was used to lold the mice while $\mathrm{x}$-rays were applied.

31 X-rayed ovary (B 4 ).

32 A portion of an $x$-rayed ovary (D 5).

33 A portion of an $x$-rayed ovary showing an epithelial ingrowth (C 8). 

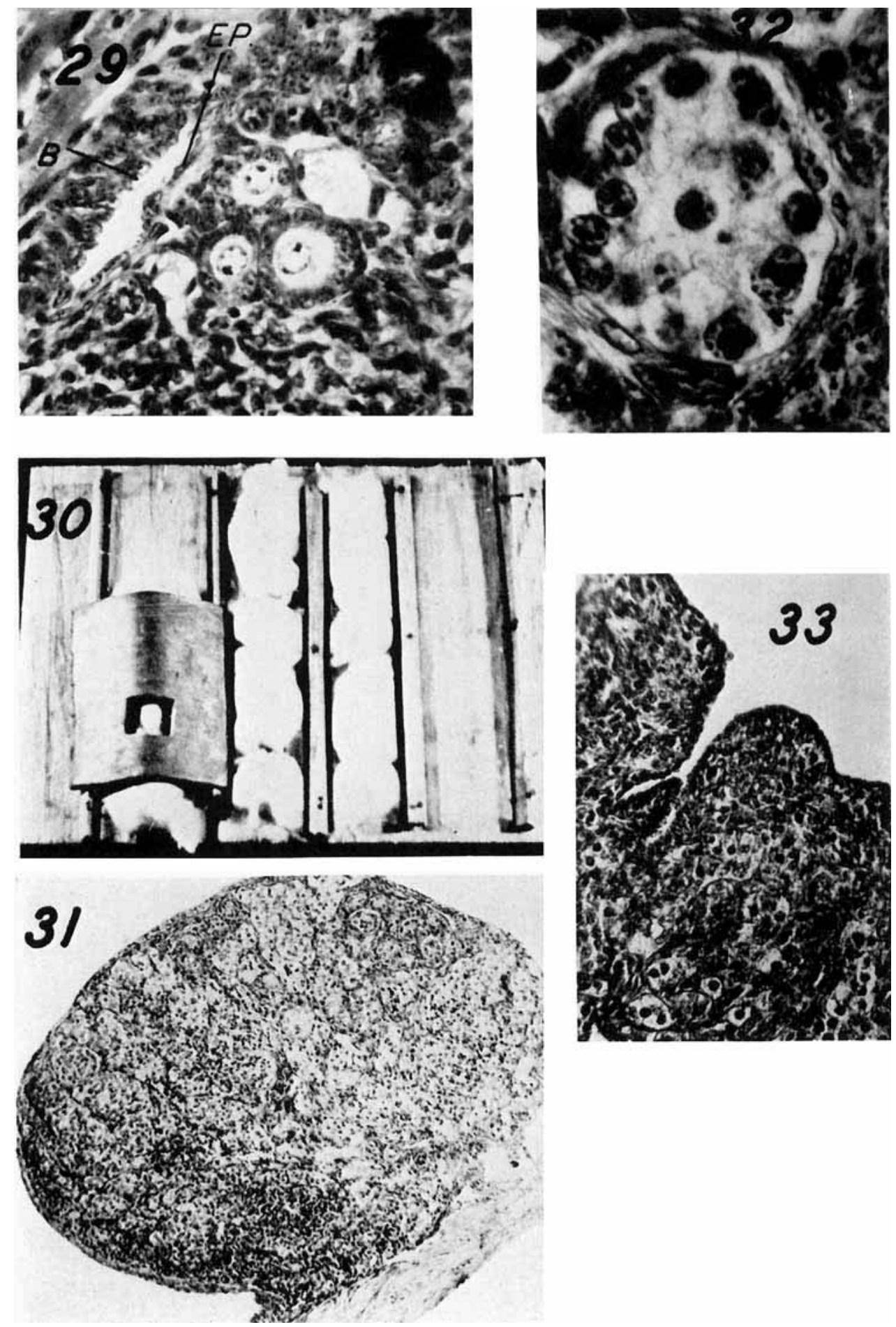